\section{Winter Survival and Second-year Spring Yields of Day-neutral Strawberry Are Influenced by Cultivar and the Presence of Low Tunnels}

\author{
Kaitlyn M. Orde ${ }^{1}$ and Rebecca Grube Sideman ${ }^{1}$
}

ADDITIONAL INDEX wORDs. day-neutral, Fragaria $\times$ ananassa, low tunnel, protected culture, spring production, winter protection

SuMmary. Day-neutral (DN) strawberry (Fragaria $\times$ ananassa) cultivars have potential to produce high yields in New England and greatly extend the period of regional strawberry production each year. However, DN strawberries have primarily been evaluated as an annual crop in cold climates; thus, winter hardiness and subsequent second-year spring yields are not well understood. Separate DN plantings were established as dormant bare-rooted plants in Durham, NH (U.S. Department of Agriculture hardiness zone 5b) in 2017 and 2018. During their first year of growth and fruit production, plants were grown under one of two cover treatments: a plastic-covered low tunnel or the traditional open field environment (open beds). In November, plants were covered with either straw much (Winter 2017-18) or rowcover (Winter 2018-19) for low-temperature protection during the winter months. In the spring of the second year when winter protection was removed, the same cover treatments (low tunnel or open bed) were re-administered to plants. Plant survival was affected by year and cultivar, with average survival rates of $82 \%$ and $98 \%$ in Spring 2018 and Spring 2019, respectively. Plant survival ranged from $34 \%$ ('Monterey') to $99 \%$ ('Aromas') in 2018 , and $92 \%$ ('Albion') to $100 \%$ ('San Andreas' and 'Seascape') in 2019. Cultivar significantly affected total and marketable yields in both years, and marketable yields ranged from 35.8 to 167.3 $\mathrm{g} /$ plant in 2018 and 121.6 to $298.6 \mathrm{~g} /$ plant in 2019 . The greatest marketable yields were produced by 'Aromas', 'Cabrillo', 'San Andreas', 'Seascape', and lowtunnel 'Sweet Ann'. In 2019, 'Cabrillo', 'San Andreas', and 'Seascape' produced greater marketable yields during the 6-week second-year season than they had during the plants' first year of fruit production the previous year, which spanned 18 weeks. Low tunnels hastened fruit ripening in the spring and result in earlier fruit harvests, and in 2019, marketable yields were significantly greater under low tunnels for the first 1 to 3 weeks, depending on cultivar. Total and marketable yields were unaffected by low tunnels in 2018 , but were significantly greater under low tunnels in 2019. For cultivars in the 2019 experiment, the increase in marketable yield under low tunnels (compared with open beds) ranged from 92.3 to 166.5 $\mathrm{g} /$ plant, except for Sweet Ann, for which marketable yields were $256.6 \mathrm{~g} /$ plant greater under low tunnels than on open beds. Using a conservative direct market rate of $\$ 4.50 / 1 b$, the second-year spring yields produced in the present study had a direct market value of between $\$ 3899 / \mathrm{ha}$ and $\$ 95,647 / \mathrm{ha}$, depending on cultivar and year. We demonstrate that it is not only possible to overwinter DN strawberry plants in northern New England, but that the second-year yield may even exceed first-year production. The results from the present study indicate great potential for profitability from an overwintered DN crop.

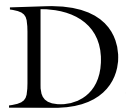
ay-neutral $(\mathrm{DN})$ strawberry (Fragaria $\times$ ananassa) cultivars can be successfully grown in what are considered to be cold areas of North America, including the upper midwest and northeast regions of the United States, and eastern Canada, where they have produced competitive annual yields (Anderson et al., 2019; Orde and Sideman, 2019; Petran et al., 2016; Pike, 2011; Pritts, 2016, 2017; Pritts and McDermott, 2017; Van Sterthem et al., 2017; Weber et al., 2018; Willden et al., 2021). In the northeastern United States, as a result of

\begin{tabular}{llll}
\hline $\begin{array}{l}\text { Units } \\
\text { To convert U.S. to SI, } \\
\text { multiply by }\end{array}$ & U.S. unit & SI unit & $\begin{array}{l}\text { To convert SI to U.S., } \\
\text { multiply by }\end{array}$ \\
\hline 0.4047 & $\mathrm{acre}(\mathrm{s})$ & $\mathrm{ha}$ & $2.471 \mathrm{l}$ \\
0.3048 & $\mathrm{ft}$ & $\mathrm{m}$ & 3.2808 \\
0.0929 & $\mathrm{ft}^{2}$ & $\mathrm{~m}^{2}$ & 10.7639 \\
2.54 & $\mathrm{inch}(\mathrm{es})$ & $\mathrm{cm}$ & 0.3937 \\
0.4536 & $\mathrm{lb}$ & $\mathrm{kg}$ & 2.2046 \\
1.1209 & $\mathrm{lb} / \mathrm{acre}$ & $\mathrm{kg} \cdot \mathrm{ha}^{-1}$ & 0.8922 \\
25.4 & $\mathrm{mil}(\mathrm{s})$ & $\mu \mathrm{m}$ & 0.0394 \\
28.3495 & $\mathrm{oz}$ & $\mathrm{g}$ & 0.0353 \\
33.9057 & $\mathrm{oz} / \mathrm{yard}{ }^{2}$ & $\mathrm{~g} \cdot \mathrm{m}^{-2}$ & 0.0295 \\
1 & $\mathrm{ppm}$ & $\mathrm{mg} \cdot \mathrm{kg}^{-1}$ & 1 \\
2.2417 & ton $(\mathrm{s}) / \mathrm{acre}^{\circ}$ & $\mathrm{Mg} \cdot \mathrm{ha}^{-1}$ & 0.4461 \\
$\left({ }^{\circ} \mathrm{F}-32\right) \div 1.8$ & ${ }^{\circ} \mathrm{F}$ & ${ }^{\circ} \mathrm{C}$ & $\left({ }^{\circ} \mathrm{C} \times 1.8\right)+32$
\end{tabular}

the pervasive utilization of short-day cultivars, regionally produced strawberry fruit are typically available for only 4 to 6 weeks each year, from June to early July. DN strawberry cultivars present the opportunity to extend regional strawberry production by an additional 18 to 20 weeks (Orde and Sideman, 2019; Pritts and McDermott, 2017), allowing commercial strawberry growers to produce fresh fruit from early June into November, for $\approx 24$ weeks each year.

Past research in northern locations with $\mathrm{DN}$ cultivars has primarily focused on first-year production, and therefore evaluated DN cultivars as an annual crop (Anderson et al., 2019; Petran et al., 2016; Van Sterthem et al., 2017; Willden et al., 2021). However, most commercial strawberry producers in New England are accustomed to overwintering strawberry plants, and depending on the production system (plastic mulch or matted-row), growers typically keep strawberry plantings for two to three fruiting seasons. Given this practice and what are perceived to be relatively high costs associated with establishing plasticulture production systems, it is likely that growers who adopt DN cultivars will have interest in overwintering plants for subsequent fruiting seasons.

Despite a perception that $\mathrm{DN}$ cultivars are not hardy, preliminary studies and on-farm reports suggest it is possible to overwinter DN cultivars in the northeastern United States and that potential exists for early fruit production and high yields during the second year. Straw mulch or rowcover have been used for winter protection by researchers and growers in the region, who report that winter survival rates vary from poor to 
excellent, depending on cultivar and year (Pike, 2011; Pritts, 2016). High second-year yields have been reported by a strawberry grower in Maine (D. Pike, personal communication; Pike, 2011) and, in upstate New York, second-year yields have been nearly as high as the first year (Pritts, 2016). Pike (2011) reported that DN cultivars fruited 2 to 3 weeks ahead of short-day plants in their second year, and Lewers (2015) obtained earlier harvests from DN plants covered by low tunnels than from short-day plants grown on open beds. This suggests that overwintered DN plants may further stretch the strawberry fruiting season earlier in the spring, especially if plants are covered by low tunnels.

Low tunnels are small protective structures that are assembled in the field and typically cover one bed of strawberry plants. They have previously been shown to increase the percent marketable yield of DN cultivars (Anderson et al., 2019; Lewers et al., 2017; Orde and Sideman, 2019; Pritts, 2017; Van Sterthem et al., 2017), and occasionally the actual marketable yield per plant (Lewers et al., 2017; Orde and Sideman, 2019; Resende et al., 2010). In New Hampshire, low tunnels have not accelerated fruit ripening of DN plants in their first year of fruit production [the year of planting (Orde and Sideman, 2019)], but there is evidence that low tunnels may hasten flowering and ripening when imposed over already

Received for publication 15 Sept. 2020. Accepted for publication 2 Dec. 2020.

Published online 11 January 2021.

${ }^{1}$ Department of Agriculture, Nutrition and Food Systems, University of New Hampshire, 38 Academic Way, Durham, NH 03824

We thank farm, greenhouse, and technical staff at the University of New Hampshire and Kathleen Demchak at The Pennsylvania State University. We are grateful to Ryan Dickson and Samantha Willden for their thoughtful reviews of our manuscript. This work was funded by the National Institute of Food and Agriculture, U.S. Department of Agriculture, Specialty Crops Research Initiative under Award Number 2014-51181-22380 (TunnelBerries). Partial funding was provided by the New Hampshire Vegetable and Berry Growers' Association and New Hampshire Agricultural Experiment Station. This is Scientific Contribution Number 2868. This work was supported by the USDA National Institute of Food and Agriculture Hatch Project NH00635.

R.G.S. is the corresponding author. E-mail: becky. sideman@unh.edu.

This is an open access article distributed under the CC BY-NC-ND license (https://creativecommons.org/ licenses/by-nc-nd/4.0/).

https://doi.org/10.21273/HORTTECH04734-20 established plants, by as much as 1 to 3 weeks (Laugale et al., 2017; Lewers et al., 2017; Pritts, 2016).

Aside from the aforementioned on-farm work and preliminary unpublished trials, to our knowledge, there are no replicated studies investigating the winter survival rate or second-year yields of DN strawberry cultivars in New England. Such information is necessary to understand the economic risks associated with overwintering the crop, and to develop recommendations for commercial growers throughout the region.

Objectives of this study were to assess winterhardiness of several widely available DN cultivars and to measure cultivar and low-tunnel effects on crop earliness and yield during the second-year spring fruiting season. To address these questions, we overwintered two separate DN plantings at the end of their first year of fruit production. The plastic film that covered low tunnels was removed in November and plants were protected with straw or rowcover for the winter (the winter protection material and degree of low-tunnel disassembly depended on year). After winter protection was removed in the early spring of the second year, low tunnels were re-covered and data were collected on plant survival rate, yield, and fruiting pattern. We hypothesized that both the winter survival rate and second-year spring yields would be influenced by cultivar.

\section{Materials and methods Site}

Experiments were conducted at the University of New Hampshire Agricultural Experiment Station Woodman Horticultural Research Farm in Durham, NH (lat. $43^{\circ} 15^{\prime} \mathrm{N}$, long. $\left.70^{\circ} 93^{\prime} \mathrm{W}\right)$. The site is located in plant hardiness zone 5B [U.S. Department of Agriculture (USDA), 2012].

\section{Treatments and experimental design}

Two cover treatments were investigated: low tunnels and traditional open beds. A complete commercial low-tunnel system was used (Tunnel Flex; Dubois Agrinovations, SaintRemi, QC, Canada), which was covered by a thin transparent low-tunnel film containing small circular holes for ventilation on the lower 12 inches of the tunnel [1.5-mil film; Trioplast, Smalandsstenar, Sweden (Fig. 1)]. Specific details regarding tunnel components and set up are described in Orde and Sideman (2019). A total of eight DN cultivars were evaluated: Albion, Aromas, Monterey, Portola, San Andreas, and Seascape in 2017; and Albion, Cabrillo, Monterey, Portola, San Andreas, Seascape, and Sweet Ann in 2018. Although there is evidence that California-originating DN cultivars are actually long-day plants, especially at temperatures above $27^{\circ} \mathrm{C}$ (Sønsteby and Heide, 2007), and that Albion's productivity is enhanced following long-day conditioning (Durner, 2017), the cultivars included in the present study are widely referred to as DN plants in our region; thus, we will use this term throughout.

The experiment was arranged in a split-plot, randomized complete block design with four replications. The main-plot factor was the cover treatment (low tunnel or traditional open bed) and the sub-plot ("plot") factor was DN cultivar. Each block contained two rows (in the form of raised beds), one of each cover treatment. Plots of each cultivar were established back-to-back the length of each row and consisted of 10 (2017-18) and 14 (2018-19) plants. Additional plants were installed at

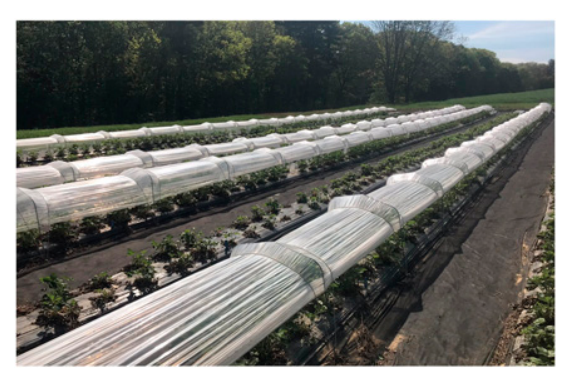

Fig. 1. Overwintered day-neutral strawberry planting at the University of New Hampshire on 22 May 2019. A complete commercial low-tunnel system (Tunnel Flex; Dubois Agrinovations, Saint-Remi, QC, Canada) was used for experiments that measured $0.7 \mathrm{~m}(2.30 \mathrm{ft})$ wide $\times$ $1.0 \mathrm{~m}(3.28 \mathrm{ft})$ high. Hoops were grounded with galvanized steel stakes [18 inches $(45.7 \mathrm{~cm})$ long] and covered with a thin 1.5 -mil $(38.10 \mu \mathrm{m})$ transparent film designed for low tunnels that contained small circular holes for ventilation on the lower 12 inches $(30.5 \mathrm{~cm})$ of the tunnel. 
both ends of all eight rows as guard plants and consisted of two 'Albion' plants in 2017, and an additional plot of 'Albion', 'Cabrillo', or 'Sweet Ann' in 2018 .

\section{Plant establishment}

Crop establishment and management during the first year of growth and fruit production are detailed in Orde and Sideman (2019). Dormant bare-rooted DN plants were established in the spring of both 2017 (28 Apr. 2017) and 2018 (7-11 May 2018) into raised beds that were $6 \mathrm{ft}$ apart (center to center), covered with black plastic mulch (1.25-mil embossed mulch; Poly Expert, Laval, QC, Canada), and equipped with a single line of 10-mil drip irrigation tape with a 12 -inch emitter spacing (T-tape; Rivulis Eurodrip, San Diego, $\mathrm{CA}$ ). The plant spacing was 16 inches within row to accommodate highvigor cultivars (Lantz et al., 2010), and plants were installed in a double staggered row 12 inches apart, for a plant density of 13,068 plants/acre. Plots consisted of 10 plants in 2018 and 14 plants in 2019.

Adjacent fields were used for experiments, both of which were cropped with brussels sprouts (Brassica oleracea Gemmifera group) in the year before use. Soil was amended with $60 \mathrm{lb} /$ acre of both nitrogen (27N-0P-0K, calcium ammonium nitrate; Kirby Agri, Lancaster, PA) and potassium $(0 \mathrm{~N}-0 \mathrm{P}-42.3 \mathrm{~K}$, sulfate of potash; North Country Organics, Bradford, VT) before bed formation, based on soil test results and fertility recommendations for strawberry (Lantz et al., 2010). Additional nutrition was provided to plants once per week through the drip irrigation system from 12 June to 27 Oct. 2017 and 2 July 2018 to 17 Oct. 2018. In 2017, fertigation began at a rate of $2.5 \mathrm{lb} /$ acre nitrogen $(\mathrm{N}), 0.6$ $\mathrm{lb} /$ acre phosphorus $(\mathrm{P}), 2.4 \mathrm{lb} /$ acre potassium (K) $(21 \mathrm{~N}-2.2 \mathrm{P}-16.6 \mathrm{~K}$, Jack's All Purpose LX soluble fertilizer; JR Peters, Allentown, PA). When a foliar nutrient analyses conducted in July 2017 indicated plants were below the optimal range of $\mathrm{N}$ and $\mathrm{P}$, application rates were increased to $5 \mathrm{lb} /$ acre $\mathrm{N}, 1.2 \mathrm{lb} /$ acre $\mathrm{P}$, and $4.7 \mathrm{lb} /$ acre K on 1 Aug. 2017 and continued at this rate throughout the remainder of the 2017 season and the entire 2018 experiment.

\section{Overwintering}

Following the first full year of growth and fruit production, which spanned from approximately late June into November of both years, experiments were overwintered. The 2017 planting was overwintered (Winter 2017-18) into Spring 2018 (“2018”), and the 2018 planting was overwintered (Winter 2018-19) into Spring 2019 (“2019”).

As is typical across New England, plants were covered in November for the duration of the winter to prevent winter injury (Pritts and Handley, 1998; Schloemann, 2004). The material used for winter protection in the 2017-18 experiment was a 3- to 4inch-thick layer of straw (applied 29 Nov. 2017). To prevent low-tunnel components from interfering with straw, the plastic film that covered low tunnels was removed and stored in a barn for the winter. We opted to remove the film from the field for the winter (instead of laying it on the ground on one side of the bed) for several reasons: it was very quick and easy remove, we wanted to reduce any potential film degradation, and plastic that is left in the field over the winter can become dirty and opaque. However, low-tunnel hoops, stakes, and anchor pipes were left in place in the field during the winter for easy lowtunnel reassembly in Spring 2018. Straw was applied at a rate of five 40 -lb bales per $100 \mathrm{ft}^{2}$, which we estimate to be $\approx 6$ tons/acre (assuming 300 bales/acre). Straw was applied to raised beds only (not between aisles), and we were conscientious to cover the edges of beds to ensure straw was not blown off by wind, which growers have cited as an issue with using straw for winter protection on plastic mulched beds.

Due to the high costs and difficulty of acquiring straw mulch in 2018 , the 2018-19 planting was protected for the winter with a $1.25-\mathrm{oz} /$ yard ${ }^{2}$ rowcover (Typar Xavan T5131; Dupont, Wilmington, DE) that was applied on 15 Nov. 2018. Except for the anchor pipes at the ends of rows, all low-tunnel components were removed before the application of rowcover.

\section{Second-year management}

Winter protection was removed before mid-April in both experiments; on 3 Apr. 2018 and 12 Apr.
2019, as recommended by Pritts and Handley (1998). For weed control between rows, in 2018 , the straw that covered plants for the winter was raked between rows. In 2019, a 1.6$\mathrm{oz} /$ yard $^{2}$ black weed mat (Covertan Pro Black Weed Mat; Berry Global, Evansville, IN) remained between rows from the previous year.

Using clippers, dead plant material was mostly removed from overwintered plants, as recommended by Pike (2011). Low tunnels were reassembled over plants on 3 Apr. 2018 and 19 Apr. 2019, soon after winter protection was removed. Low-tunnel sides were lowered to the ground ("closed") to increase temperatures around plants and encourage growth. When outside air temperatures were expected to exceed $75^{\circ} \mathrm{F}$ and there was little risk of precipitation, lowtunnel sides were lifted to prevent excessively high temperatures inside tunnels, which can reach nearly $20^{\circ} \mathrm{F}$ warmer than open beds (Orde and Sideman, 2019). Plants received the same cover treatment (low tunnel or open bed) during this second-year spring season as they had during their first year of growth.

In May 2018, a commercial plant tissue test was conducted using the methods outlined by University of New Hampshire Extension (University of New Hampshire, 2020). Young but completely unfurled leaves were collected from five plants in each of the eight 'Aromas' replicates, for a total of 40 leaves. 'Aromas' was used because it was highly vigorous and there were a number of leaves to choose from. Leaves were placed in a paper bag and air dried in a greenhouse. The leaf tissue analyses showed that $\mathrm{N}(3.67 \%)$ and $\mathrm{P}$ $(0.51 \%)$ were slightly above the optimum range for strawberry $(2.1 \%$ to $3.25 \%$ and $0.25 \%$ to $0.5 \%$, respectively), and that calcium (0.54\%) was just below the optimum range $(0.6 \%$ to $2.0 \%)$. Potassium $(2.33 \%)$, magnesium $(0.33 \%)$, boron $(30.99 \mathrm{ppm})$, copper (10.3 ppm), iron (94.56 ppm), manganese (154.94 ppm), and zinc $(35.09 \mathrm{ppm})$ were within the optimum range for strawberry (1.2\% to $3.0 \%, 0.3 \%$ to $0.65 \%, 20$ to $85 \mathrm{ppm}, 5$ to $25 \mathrm{ppm}, 50$ to $325 \mathrm{ppm}$, 40 to $250 \mathrm{ppm}$, and 15 to $65 \mathrm{ppm}$, respectively). Thus, plants were fertilized only once during each spring season on 8 June 2018 and 18 June 
2019 , at a rate of $5 \mathrm{lb} /$ acre $\mathrm{N}, 1.2$ $\mathrm{lb} /$ acre $\mathrm{P}$, and $4.7 \mathrm{lb} /$ acre K $(21 \mathrm{~N}-$ 2.2P-16.6K, Jack's All Purpose LX). Fertilizer was applied through the drip irrigation system. Runners were removed once in each year on 5 June.

\section{Data collection}

Winter survival. Before the application of winter protection, a final living plant count was collected on 15 Nov. 2017 and 1 Nov. 2018. A living plant count was collected again once plants emerged from dormancy and put on new growth the following spring, when it was clear the plants had survived the winter season. This surviving plant count was conducted on 5 June 2018 and 18 June 2019.

YIELD. All ripe fruit were harvested twice per week. U.S. No. I Grade fruit, which had a diameter $>0.75$ inch (USDA, 2006) and generally weighed $>7 \mathrm{~g}$, were considered marketable. Water damage, misshapen fruit, fruit coated in soil, and rot were common reasons for unmarketability. Fruit from each plot were separated into marketable and unmarketable groups and weighed and counted by group. For each harvest, per-plant yield (total and marketable) was calculated by dividing the total plot yield by the number of living plants in the plot.
Temperature. Air and soil temperatures were recorded each hour from 1 Dec. to 31 Mar. in both years using an outdoor temperature sensor (Hobo U12-008 4-channel logger; Onset Computer Corp., Bourne, MA). Air temperature was collected under a solar radiation shield that was either placed on top of raised beds and surrounded by straw mulch (Winter 2017-18) or placed under rowcover (Winter 2018-19) $(\mathrm{n}=1)$. Soil temperatures were collected at soil depth of 3 inches. In 2019, spring air and soil temperatures were also collected from 21 May to 10 July $(\mathrm{n}=$ 2 ). Daily mean, minimum, and maximum temperatures are reported.

\section{Data analysis}

Analysis of variance with JMP Pro 13 (SAS Institute, Cary, NC) was used to evaluate the effects of year, cover treatment (main plot), and cultivar (sub-plot) on yield (total and marketable), weekly marketable yield, percent marketable yield by weight, and plant survival. Year effects considered only the cultivars present in both experiments. Marketable yield data were analyzed separately by week to determine statistical differences between cover treatments within a given week. Plant survival rates and percent marketable yield values were arcsine-transformed before analysis.
Block was specified as a random effect. When an overall $\mathrm{F}$ test was significant $(P \leq 0.05)$, means were compared using Tukey's honestly significant difference test or Student's $t$ test at $P \leq 0.05$. In the case of a significant interaction among treatments, results are explained and/or presented separately for all treatment combinations.

\section{Results}

WiNTER TEMPERATURES. Daily fluctuations in temperature were generally greater under rowcover during Winter 2018-19 than under straw mulch during Winter 2017-18 (Fig. 2 ). The most extreme minimum air temperature was recorded under straw on 3 Feb. 2018 (Winter 2017-18) when the air temperature dropped below $10{ }^{\circ} \mathrm{F}$ [a potential benchmark for major injury (Marini and Boyce, 1979; Palonen and Lindén, 2002)] for 14 consecutive hours and reached a low of $0.3{ }^{\circ} \mathrm{F}$ (Fig. 2). During this same winter, there were four other separate occasions when air temperatures fell below $10^{\circ} \mathrm{F}$. During Winter 2018-19, there were seven occasions when temperatures dropped below $10{ }^{\circ} \mathrm{F}$ but the coldest air temperature recorded was only $5.1{ }^{\circ} \mathrm{F}$ (Fig. 2). Although extreme minimum temperatures were colder in Winter 2017-18 than
2017-18

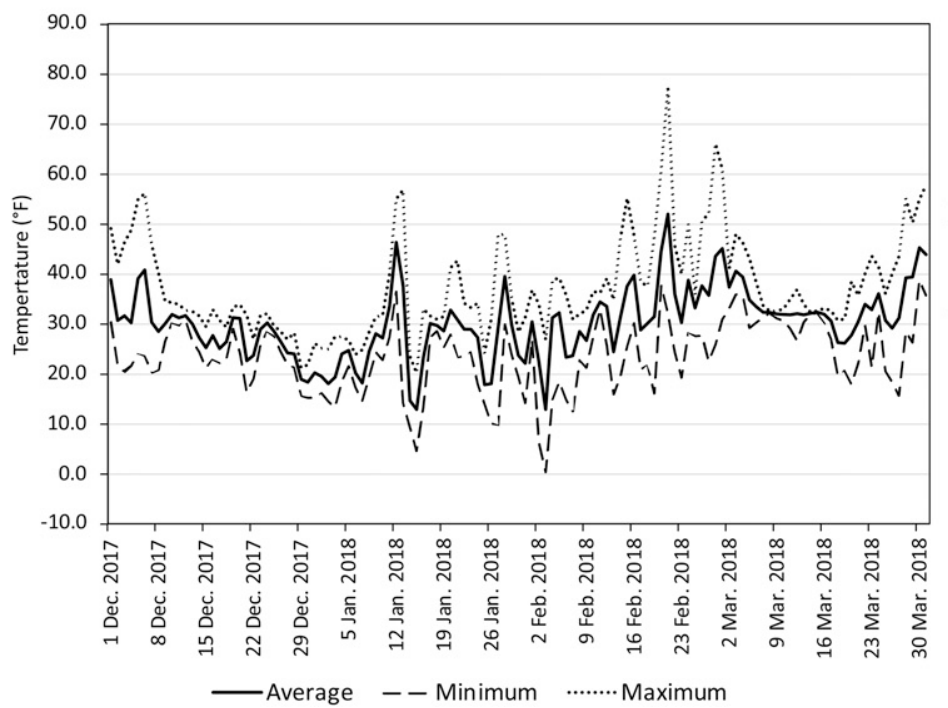

2018-19

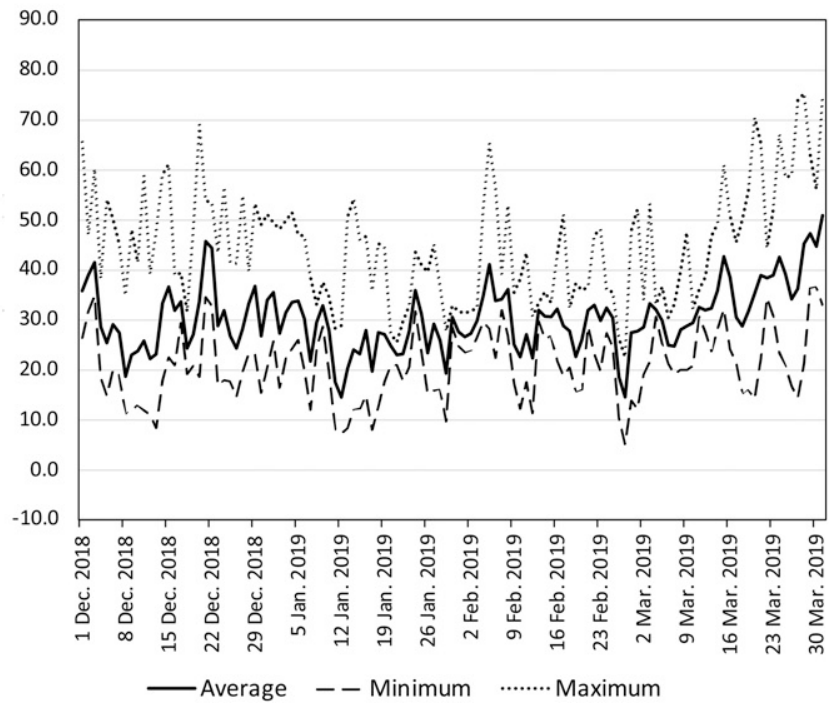

Fig. 2. Daily (24-h) average, minimum, and maximum air temperatures for overwintered strawberry experiments in Durham, NH. Temperatures were recorded under a 4 -inch $(10.2-\mathrm{cm})$-thick layer of straw during Winter 2017-18, and a single layer of 1.25-oz/yard ${ }^{2}\left(42.328 \mathrm{~g} \cdot \mathrm{m}^{-2}\right)$ rowcover (Typar Xavan T5131; Dupont, Wilmington, DE) during Winter 2018-19. Air temperatures were collected within solar radiation shields that were set on top of raised beds. Temperatures are for the period of 1 Dec. through 31 Mar. $(\mathrm{n}=1) ;\left({ }^{\circ} \mathrm{F}-32\right) \div 1.8={ }^{\circ} \mathrm{C}$. 
Winter 2018-19, the monthly average minimum temperature was colder in all months (December, January, February, and March) of Winter 2018-19 (data not shown). The monthly average maximum temperatures were greater during Winter 2018-19 than Winter 2017-18, with the exception of February. Soil temperatures reached a low of $31.3^{\circ} \mathrm{F}$ during Winter 2017-18 and $28.5^{\circ} \mathrm{F}$ during Winter 2018-19.

Winter survival. Considering only the cultivars that were present in both years of experiments (Albion, Monterey, Portola, San Andreas, and Seascape), winter survival rates were significantly influenced by year $(P<0.001)$ and were an average of $16 \%$ higher in $2019(98 \%)$ than 2018 $(82 \%)$ (Table 1). There was also a significant year $\times$ cultivar interaction $(P<$ 0.001 ) (Table 1) due to Monterey having a lower survival rate than other cultivars in 2018 , but a survival rate comparable to other cultivars in $2019(P \leq 0.05)$. Given this interaction, and the fact that 'Aromas', 'Cabrillo', and 'Sweet Ann' were present in only 1 of 2 years, plant survival data are also presented separately by year (Table 1 ).

There were significant differences among cultivars in winter survival rate in both years $(P<0.0001$ and $P<0.01$ in 2018 and 2019, respectively) (Table 1 ). In 2018, 'Aromas' (99\%), 'San Andreas' (97\%), 'Seascape' (96\%), and 'Albion' $(85 \%)$ had the highest winter survival rates, and 'Monterey' the lowest (34\%). In 2019, all cultivars had a survival rate greater than $90 \%$, with $100 \%$ of San Andreas and Seascape plants surviving the winter (Table l). The cover treatment (low tunnel or open bed) that had been imposed on plants during the first growing season did not influence subsequent winter survival.

SPring temperatures. Average minimum and maximum air temperatures in the Spring 2019 season (21 May to 10 July 2019) were higher under low tunnels than on open beds, with minimum temperatures averaging $53.5^{\circ} \mathrm{F}$ (low tunnel) and $52.6^{\circ} \mathrm{F}$ (open bed), and maximum temperatures averaging $82.4^{\circ} \mathrm{F}$ (low tunnel) and $77.3{ }^{\circ} \mathrm{F}$ (open bed). However, the greater maximum air temperature under low tunnels was because lowtunnel sides were closed for a portion

Table 1. Average percent survival of day-neutral strawberry plants overwintered in Durham, NH, from Fall 2017 into Spring 2018 (2018), and Fall 2018 into Spring 2019 (2019). Cover treatments (low tunnel and open bed) refer to the treatments imposed on plants during their first year of growth, before overwintering. For winter protection, plants were covered with a 4-inch (10.2$\mathrm{cm}$ )-thick layer of straw during Winter 2017-18 (applied 29 Nov. 2017) and a single layer of $1.25-\mathrm{oz} / \mathrm{yard}^{2}\left(42.328 \mathrm{~g} \cdot \mathrm{m}^{-2}\right)$ rowcover (Typar Xavan T5131; Dupont, Wilmington, DE) during Winter 2018-19 (applied 15 Nov. 2018). Straw and rowcover winter protection were removed on 3 Apr. 2018 and 12 Apr. 2019, respectively [ $n=24(2017-18)$ and $n=28$ (2018-19) for cover treatment, and $n=4$ for cultivar $]$.

\begin{tabular}{|c|c|c|}
\hline & \multicolumn{2}{|c|}{ Winter survival (\%) } \\
\hline & 2018 & 2019 \\
\hline Year $^{\mathrm{z}}$ & $82 \mathrm{~b}$ & $98 \mathrm{a}$ \\
\hline \multicolumn{3}{|l|}{ Cover treatment $\mathrm{t}^{\mathrm{y}}$} \\
\hline Low tunnel & 87 & 98 \\
\hline Open bed & 85 & 98 \\
\hline \multicolumn{3}{|l|}{ Cultivar } \\
\hline Albion & $85 \mathrm{ab}^{\mathrm{x}}$ & $92 \mathrm{c}$ \\
\hline Aromas & 99 a & \\
\hline Cabrillo & & $93 \mathrm{bc}$ \\
\hline Monterey & $34 \mathrm{c}$ & $95 \mathrm{abc}$ \\
\hline Portola & $77 \mathrm{~b}$ & $99 \mathrm{abc}$ \\
\hline San Andreas & $97 \mathrm{ab}$ & $100 \mathrm{a}$ \\
\hline Seascape & $96 \mathrm{ab}$ & $100 \mathrm{ab}$ \\
\hline Sweet Ann & & $98 \mathrm{abc}$ \\
\hline \multicolumn{3}{|l|}{ Significance } \\
\hline Cover treatment & 0.798 & 0.881 \\
\hline Cultivar & $<0.0001$ & 0.002 \\
\hline Cover treatment $\times$ cultivar & 0.574 & 0.233 \\
\hline Year $^{\mathrm{z}}$ & \multicolumn{2}{|c|}{$<0.0001$} \\
\hline Year $\times$ cover treatment & \multicolumn{2}{|c|}{0.817} \\
\hline Year $\times$ cultivar & \multicolumn{2}{|c|}{0.001} \\
\hline Year $\times$ cover treatment $\times$ cultivar & \multicolumn{2}{|c|}{0.895} \\
\hline
\end{tabular}

${ }^{2}$ Year and year $\times$ treatment interactions determined using the five cultivars included in both years of the study (Albion, Monterey, Portola, San Andreas, and Seascape). Year means not sharing a letter are significantly different by Student's $t$ test at $P \leq 0.05$.

${ }^{y}$ Cover treatment refers to whether plants were grown on traditional open beds or under low tunnels during their first year of growth, not to winter protection strategy.

${ }^{\mathrm{x}}$ Within year, cultivar means followed by the same letter are not significantly different by Tukey's honestly significant difference test at $P \leq 0.05$.

of this period, which increased daily maximum temperatures compared with open beds (Fig. 3A). When low-tunnel sides were vented, daily maximum temperatures were more similar between the two cover treatments (Fig. 3B). The greatest difference in air temperature between cover treatments occurred on 30 May 2019 , when the air temperature was $20^{\circ} \mathrm{F}$ greater under closed low tunnels than open beds at 1:00 PM. Maximum soil temperatures were greater on open beds $\left(80.1^{\circ} \mathrm{F}\right)$ than under low tunnels $\left(79.8^{\circ} \mathrm{F}\right)$, but not substantially. Minimum soil temperatures were lower on open beds, by $1.1^{\circ} \mathrm{F}$ (data not shown).

Yield, FRUITING PATTERN, AND PERCENT MARKETABLE YIELD. Ripe fruit were harvested beginning on
29 May in both years, $56 \mathrm{~d}$ (2018) and $47 \mathrm{~d}(2019)$ after winter protection was removed, and 56 $\mathrm{d}(2018)$ and $40 \mathrm{~d}$ (2019) after low tunnels were reconstructed over plants. Fruit harvests continued until 2 July 2018 and 11 July 2019, resulting in 5- and 6-week-long spring fruiting seasons in 2018 and 2019, respectively. Weekly marketable yield was not significantly different between the low-tunnel and open-bed cover treatments for any cultivar in 2018 , but there was a distinct trend of higher marketable yields under low tunnels during the first 2 weeks of the season (Fig. 4). In 2019, all cultivars produced greater marketable yields under low tunnels in at least one of the first 3 weeks of the season, and Seascape produced greater marketable 


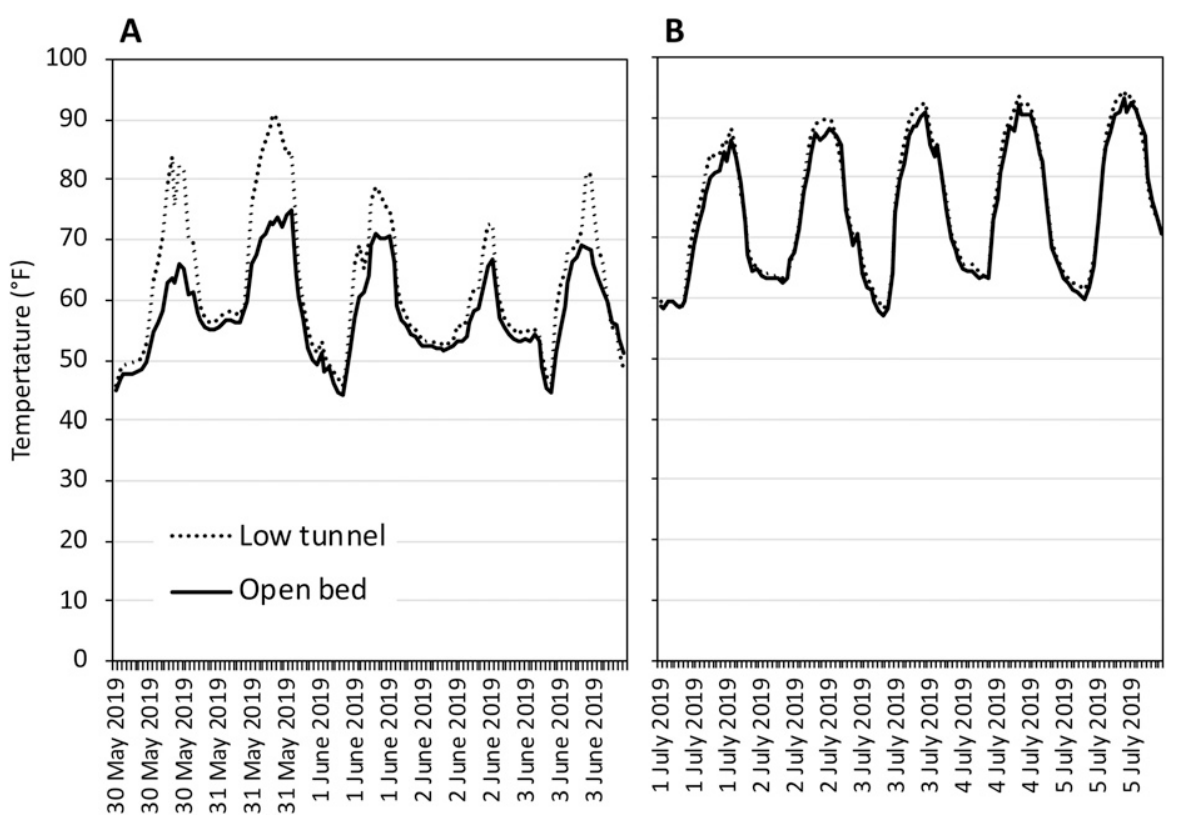

Fig. 3. Daily fluctuations in air temperature around strawberry plants for both cover treatments (low tunnel and open bed) during two representative 5 -d periods when (A) low-tunnel sides were closed (lowered to the ground), and (B) lowtunnel sides were lifted to the eave of the hoop for maximum air flow. Low tunnels were covered by a $1.5-\mathrm{mil}(38.10-\mu \mathrm{m})$ plastic and plants were on raised beds were covered with black plastic mulch $(\mathrm{n}=2) ;\left({ }^{\circ} \mathrm{F}-32\right) \div 1.8={ }^{\circ} \mathrm{C}$.

yields under low tunnels in all three of those weeks (Fig. 4).

Yield is presented in $\mathrm{g} /$ plant and is reflective of living plants only. Year $(P<0.0001)$, cultivar $(P<0.0001)$, and cover treatment $[P<0.01$ (total) and $P<0.0001$ (marketable)] all affected total and marketable per plant yield of all cultivars that were present in both years of experiments (Albion, Monterey, Portola, San Andreas, and Seascape). Significant year $\times$ cultivar $[P<0.01$ (total) and $P<0.05$ (marketable) $]$ and year $x$ cover treatment $(P<0.0001)$ interactions also occurred; and thus, we have present results separately by year.

Total and marketable yields were higher in 2019 than 2018 for all cultivars. Cover treatment affected yield in 2019 only, when total and marketable yield were 114.5 and $161.3 \mathrm{~g} /$ plant greater under low tunnels than open beds, respectively (Table 2$)$. There was a barely significant cover $\times$ cultivar interaction in $2019(P$ $=0.049)$ because Sweet Ann had a much larger marketable yield differential between low tunnels and open beds than the other cultivars. Compared with open beds, the marketable yield increase under low tunnels was $256.6 \mathrm{~g} /$ plant for 'Sweet Ann', whereas it was only 92.3-166.5 g/ plant for all other cultivars.

Cultivar affected total yield in 2018 and $2019[P<0.0001$ (Table 2)]. In 2018, 'Aromas' (237.7 g/ plant), 'San Andreas' (186.0 g/plant), and 'Seascape' (161.6 g/plant) produced the highest total yields, and 'Aromas' and 'San Andreas' had greater total yields than 'Albion' $(65.2 \mathrm{~g} /$ plant $)$ and 'Monterey' (46.8 $\mathrm{g} /$ plant $)(P \leq 0.05)$. 'Aromas' could not be obtained for the 2019 experiment, but 'San Andreas' (438.7 g/ plant) and 'Seascape' (4l1.6 g/plant) again had the highest total yields, followed by 'Cabrillo' (371.9 g/plant) and 'Sweet Ann' (405.2 g/plant), which were all higher yielding than 'Monterey' (172.9 g/plant) and 'Portola' $(200.6 \mathrm{~g} /$ plant $)(P \leq 0.05)(\mathrm{Ta}-$ ble 2).

Differences between cultivars in marketable yield mostly mirrored total yield in 2018, but less so in 2019, when Seascape $(298.6 \mathrm{~g} / \mathrm{plant})$ and Cabrillo (296.5 g/plant) had the highest marketable yields even though they produced lower total yields compared with several other cultivars (Table 2). In 2019, 'Cabrillo', 'San Andreas', 'Seascape', and
'Sweet Ann' all had greater marketable yields than 'Albion', 'Monterey', and 'Portola' (Table 2). When the yield and survival rate of cultivars was plotted against each other, there was a moderate positive relationship between winter survival and marketable yield in $2018\left(R^{2}=\right.$ $0.59)$, but almost no relationship in $2019\left(R^{2}=0.08\right)$ (correlations not shown).

The percent marketable yield was unaffected by cover or cultivar treatments in 2018, when it ranged from $67 \%$ (Seascape) to $75 \%$ (Albion) (Table 2). In 2019 a cover $\times$ cultivar interaction occurred $(P<0.0001)$ and low tunnels increased the percent marketable yield of Albion, Monterey, Portola, San Andreas, and Sweet Ann, by $23 \%, 40 \%, 40 \%, 25 \%$, and $52 \%$, respectively (Table 2 ).

Total marketable yields during the second-year spring season are compared with total first-year marketable yields of the same plants in Fig. 5, for both experiments (2018 and 2019). The plants in the 201718 experiment had substantially higher marketable yields during their first year of production (2017) than the following spring (2018). The 2018-19 experiment had more similar production levels between both periods (Fig. 5). In fact, in 2019, several cultivars (Portola, San Andreas, and Sweet Ann) produced nearly identical marketable yields in the spring of the second year as they had during the entire first year, and Cabrillo, San Andreas, and Seascape produced greater marketable yields in the spring of the second year than they had during the entire first year (296.5 vs. $160.0 \mathrm{~g} /$ plant, 255.7 vs. $231.2 \mathrm{~g} /$ plant, and 298.6 vs. 126.4 g/plant, respectively) (Fig. 5).

ECONOMICS OF OVERWINTERING. Per hectare marketable yields (Table 2 ) adjusted for plant mortality and corresponding gross revenue are shown in Table 3. Using a conservative direct market rate for our region of $\$ 4.50 / \mathrm{lb}$ (Davis et al., 2019; Orde and Sideman, 2019), the direct market (retail) value of the 2018 and 2019 crops ranged from $\$ 3899 /$ ha to $\$ 53,052 / \mathrm{ha}$, and $\$ 37,002 / \mathrm{ha}$ to $\$ 95,649 /$ ha, respectively (Table 3 ). Using an average (of retail and wholesale) price reported to the USDA (USDA-NASS, 2019) of $\$ 3.00 / \mathrm{lb}$, the value of the 2018 and 2019 crops 

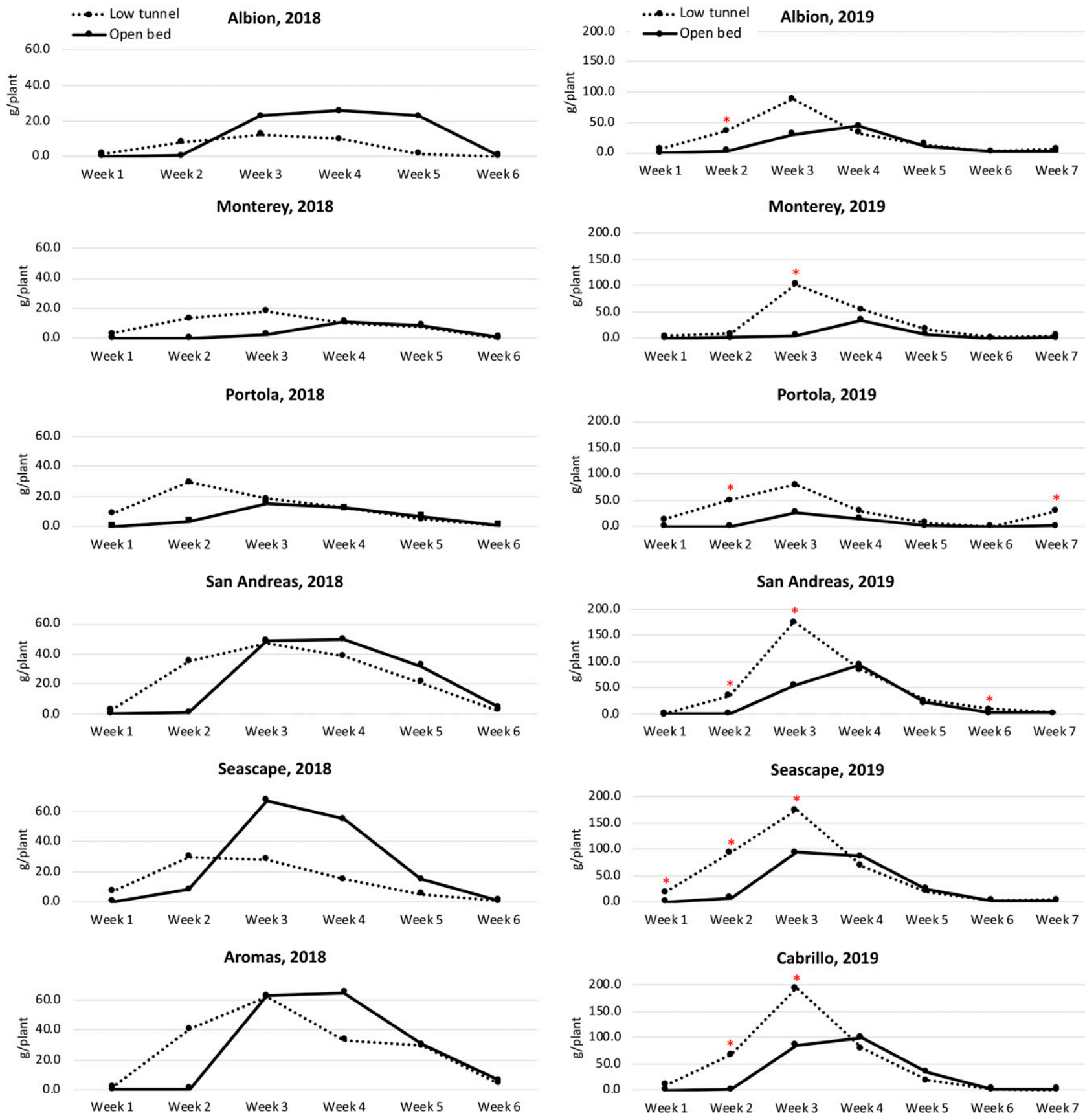

Sweet Ann, 2019

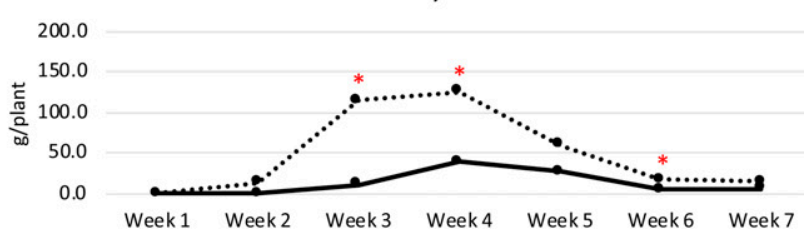

Fig. 4. Weekly marketable yield of day-neutral strawberry cultivars under both cover treatments (low tunnel and open bed) in both years of the experiments in Durham, NH. Weeks 1, 2, 3, 4, 5, 6, and 7 represents a 7 -d period and corresponds with a start date of 26 May, 2 June, 9 June, 16 June, 23 June, 30 June, and 7 July, respectively. Marketable yield is reflective of living plants only. Within cultivar and year, red asterisks indicate significant differences in yield between the two cover treatments in that week (Tukey's honestly significant difference test at $P \leq 0.05)(\mathrm{n}=4$, except for 'Monterey' in $2018 \mathrm{when} \mathrm{n}=3) ; 1 \mathrm{~g}=0.0353 \mathrm{oz}$.

ranged from $\$ 2598 /$ ha to $\$ 35,350 /$ ha and $\$ 24,655 /$ ha to $\$ 63,734 /$ ha, respectively.
Cultivar observations. Marketable fruit from the 2019 experiment are shown in Fig. 6 to illustrate fruit size and quality. Anthracnose fruit rot (Colletotrichum acutatum) was the primary cause of unmarketability on open beds in 2019, whereas there was consistently less anthracnose 
Table 2. Cover and cultivar effects on total (marketable + unmarketable), marketable, and percent marketable yield of two separate day-neutral strawberry plantings in their second year of fruit production in Durham, $\mathrm{NH}$, after being overwintered. Yield is for the period of 29 May to 2 July 2018 (2018) and 29 May to 11 July 2019 (2019). Cover treatments were traditional open field production (open bed) and low tunnels covered by a thin $1.5-\mathrm{mil}(38.10 \mu \mathrm{m})$ transparent film (low tunnel) $[\mathrm{n}=24$ (2018) and $\mathrm{n}=28$ (2019) for cover treatment, and $\mathrm{n}=4$ for cultivar].

\begin{tabular}{|c|c|c|c|c|c|c|c|}
\hline \multirow[b]{2}{*}{ Treatment } & \multicolumn{2}{|c|}{ Total yield $(\mathrm{g} / \text { plant })^{\mathrm{z}}$} & \multicolumn{2}{|c|}{$\begin{array}{c}\text { Marketable yield } \\
\text { (g/plant) }\end{array}$} & \multicolumn{3}{|c|}{ Marketable yield (\% total) } \\
\hline & 2018 & 2019 & 2018 & 2019 & 2018 & & \\
\hline Low tunnel & 121.0 & $369.5 \mathrm{a}$ & 93.5 & $288.7 \mathrm{a}$ & 72 & & \\
\hline Open bed & 138.2 & $255.0 \mathrm{~b}$ & 95.8 & $127.4 \mathrm{~b}$ & 69 & \multirow{2}{*}{$\begin{array}{l}\text { Low tunnel } \\
\qquad 84 \text { a }\end{array}$} & \\
\hline Cultivar & & $185.1 \mathrm{~b}$ & & & & & $\begin{array}{l}\text { Open bed } \\
61 \mathrm{de}\end{array}$ \\
\hline Cabrillo & & $371.9 \mathrm{a}$ & & $296.5 \mathrm{a}$ & & $86 a$ & 70 abcd \\
\hline Monterey & $46.8 \mathrm{c}$ & $172.9 \mathrm{~b}$ & $35.8 \mathrm{c}$ & $121.6 \mathrm{c}$ & 72 & $84 \mathrm{ab}$ & $44 \mathrm{ef}$ \\
\hline Portola & $80.2 \mathrm{bc}$ & $200.6 \mathrm{~b}$ & $56.9 \mathrm{bc}$ & $128.8 \mathrm{c}$ & 69 & $76 \mathrm{abcd}$ & $36 \mathrm{fg}$ \\
\hline San Andreas & $186.0 \mathrm{ab}$ & $438.7 \mathrm{a}$ & $140.5 \mathrm{ab}$ & $255.7 \mathrm{ab}$ & 71 & $69 \mathrm{bcd}$ & $44 \mathrm{ef}$ \\
\hline Seascape & $161.6 \mathrm{abc}$ & $411.6 \mathrm{a}$ & $115.1 \mathrm{abc}$ & 298.6 a & 67 & $78 \mathrm{abc}$ & $64 \mathrm{~cd}$ \\
\hline Cover $\times$ cultivar & 0.409 & 0.741 & 0.496 & 0.050 & 0.372 & \multicolumn{2}{|c|}{$<0.0001$} \\
\hline
\end{tabular}

${ }^{\mathrm{z}} \mathrm{lg}=0.0353 \mathrm{oz}$.

${ }^{y}$ Within column and year, cultivar means not connected by the same letter are significantly different by Tukey's honestly significant difference test $(P \leq 0.05)$ and cover means not connected by the same letter are different by Student's $t$ test $(P \leq 0.05)$.
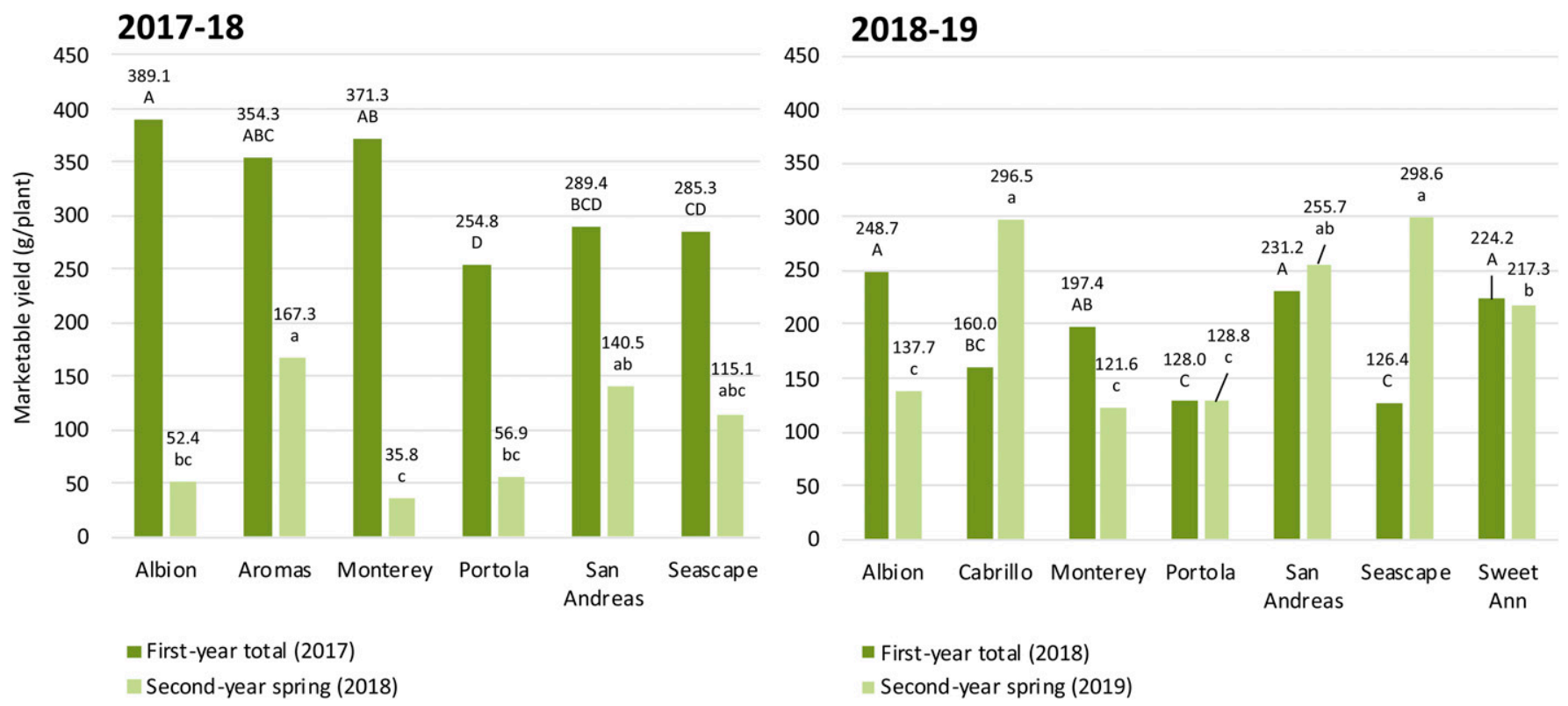

Fig. 5. Total marketable yield of day-neutral strawberry cultivars during their first year of fruit production (July through November of the year they were planted) (Orde and Sideman, 2019) and in the spring of the second year (late-May through mid-July) after plants were overwintered. Plants were covered for the winter with straw mulch during Winter 2017-18, and with a single layer of $1.25-\mathrm{oz} / \mathrm{yard}^{2}\left(42.328 \mathrm{~g} \cdot \mathrm{m}^{-2}\right)$ rowcover (Typar Xavan T5131; Dupont, Wilmington, DE) during Winter 2018-19. Marketable yield values are for living plants only and are an average of both cover treatments (open beds and low tunnels). First-year and second-year cultivar means not connected by the same uppercase and lowercase letter, respectively, are significantly different by Tukey's honestly significant difference test $(P \leq 0.05) ; 1 \mathrm{~g}=0.0353 \mathrm{oz}$.

observed under low tunnels. 'Portola' and 'Sweet Ann' appeared to have higher susceptibility to anthracnose fruit rot than the other cultivars.
'Albion', 'Aromas', 'San Andreas', and 'Monterey' produced many small fruit that were overly firm and dry, and not marketable. Conversely, the
'Cabrillo' had consistently uniformly shaped and sized fruit that were very attractive. Fruit cracking was observed in 'Cabrillo' during a short 
Table 3. Marketable yield and projected gross revenue of day-neutral strawberry cultivars in Durham, NH, for the period of 29 May to 2 July 2018 (2018) and 29 May to 11 July 2019 (2019), after plants were overwintered. Yield values have been adjusted to account for the average plant mortality of each cultivar during both winter periods; thus, marketable yields do not assume $100 \%$ plant survival and cultivar-specific mortality is reflected. Gross revenue values are provided at two rates: the average price of retail and wholesale sales reported to the USDA (2019) by New England growers [\$3.00/1b (\$6.614/kg)], and a conservative direct market (retail) rate for the Northeast region $[\$ 4.50 / 1 \mathrm{~b}(\$ 9.920 / \mathrm{kg})]$.

\begin{tabular}{|c|c|c|c|c|c|c|}
\hline \multirow[b]{3}{*}{ Cultivar } & \multicolumn{3}{|c|}{2018} & \multicolumn{3}{|c|}{2019} \\
\hline & \multirow{2}{*}{$\begin{array}{c}\text { Marketable } \\
\text { yield }\left(\mathrm{kg} \cdot \mathrm{ha}^{-1}\right)^{\mathrm{z}}\end{array}$} & \multicolumn{2}{|c|}{ Gross revenue $(\$ / h a)^{y}$} & \multirow{2}{*}{$\begin{array}{c}\text { Marketable } \\
\text { yield }\left(\mathrm{kg} \cdot \mathrm{ha}^{-1}\right)\end{array}$} & \multicolumn{2}{|c|}{ Gross revenue (\$/ha) } \\
\hline & & $\$ 3.00 / 1 b^{x}$ & $\$ 4.50 / 1 b^{w}$ & & $\$ 3.00 / 1 b$ & $\$ 4.50 / 1 b$ \\
\hline Aromas & 5,348 & 35,350 & 53,052 & & & \\
\hline Cabrillo & & & & 8,904 & 58,855 & 88,328 \\
\hline Monterey & 393 & 2,598 & 3,899 & 3,730 & 24,655 & 37,002 \\
\hline Seascape & 3,568 & 23,584 & 35,395 & 9,642 & 63,734 & 95,649 \\
\hline Sweet Ann & & & & 6,877 & 45,457 & 68,220 \\
\hline
\end{tabular}

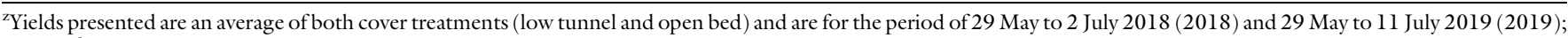
$\mathrm{l} \mathrm{kg} \cdot \mathrm{ha}^{-1}=0.8922 \mathrm{lb} /$ acre.

${ }^{y}$ Gross revenue assumes an initial planting density of 32,291 plants $/$ ha $(13,067.7$ plants $/$ acre $) ; \$ 1 /$ ha $=\$ 0.4047 /$ acre

${ }^{\mathrm{x}}$ Fresh market average price of retail and wholesale sales for the 2018 strawberry crop in New England (USDA-NASS, 2019).

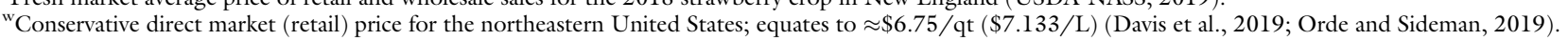

period in the first year of production (Orde and Sideman, 2019), but this was not observed at all in the second year.

Although no formal taste tests were conducted, 'Aromas', 'San Andreas', and 'Monterey' fruit occasionally had a sour and astringent taste, poor flavor, and an unacceptable texture. This was especially true for 'Aromas' in 2018 and 'San Andreas' in 2019. We noted that 'Portola' tended to have a poor eating quality due to a lack of flavor and overly soft texture. Conversely, 'Sweet Ann' had very good flavor and consistently juicy fruit.

On the final harvest day in 2019, 'Albion' and 'Seascape' plants appeared very healthy and vigorous, and contained moderate numbers of green fruit, suggesting these plants would have continued producing marketable ripe fruit had they been permitted to do so.

\section{Discussion}

The traditional strawberry season in New Hampshire uses shortday cultivars and typically lasts from mid-June through early July. The start/end date and duration of the season is highly variable from year-toyear. The overwintered DN plants in our study began producing ripe fruit by early June, with the first meaningful harvests occurring under low tunnels during the first week of June and on open beds during the second week of June.

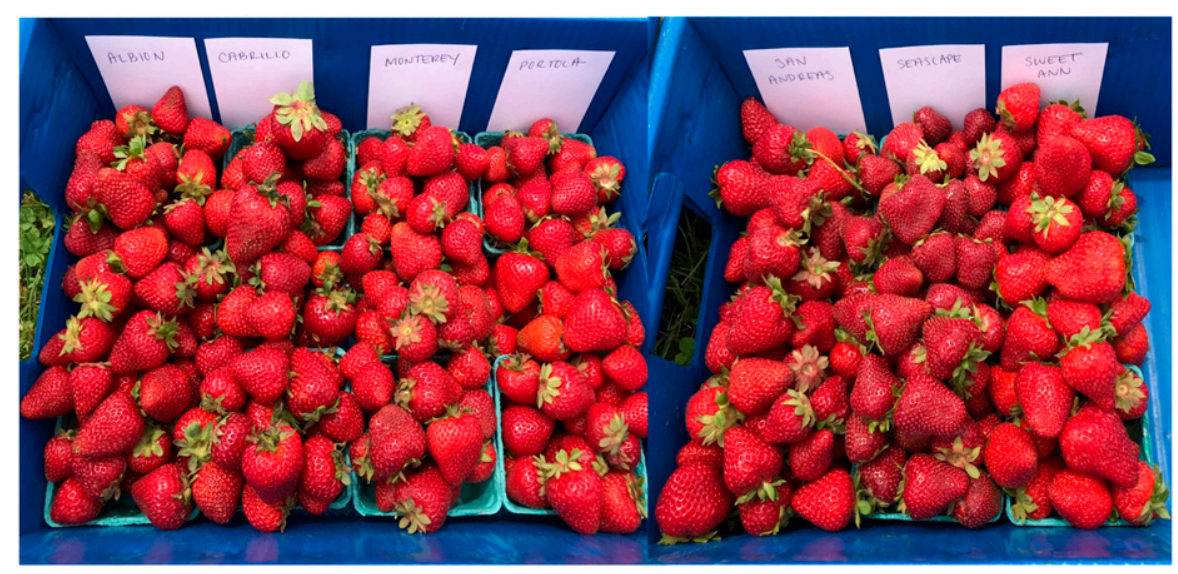

Fig. 6. An example of marketable strawberry fruit from day-neutral cultivars present in the 2019 experiment; pictured on 18 June 2019. From left to right, columns of fruit correspond with the following cultivars: Albion, Cabrillo, Monterey, Portola, San Andreas, Seascape, and Sweet Ann.

Our results showing that low tunnels advanced the start of fruit production and resulted in greater early-season production aligns with Lewers et al. (2017), Laugale et al. (2017), and Maroto et al. (1989), who report up to a 6 -week-longer season under low tunnels (Lewers et al., 2017) and significantly greater yields under low tunnels for 2 to 6 weeks at the beginning of the season (Maroto et al., 1989). Several recent studies have demonstrated that air temperatures are increased under low tunnels compared with traditional open beds, including for films with and without vent holes on the lower 12 inches of the film (Condori et al., 2017; Lewers et al., 2017; Orde and Sideman, 2019). Indeed, temperature data collected in our study show that both minimum and maximum air temperatures were increased under low tunnels, especially when low-tunnel sides were closed. Thus, by intentionally closing low-tunnel sides in the early spring, we may have promoted early-season growth and flowering. Together, these results show that the combination of DN cultivars and low tunnels are likely to extend the strawberry fruiting season 2 to 3 weeks earlier in the spring in New England. 
Our results show that DN cultivars differ both in their winterhardiness and second-year spring yields, and we observed a larger range in plant survival in $2018(34 \%$ to $99 \%)$ than in 2019 (92\% to 100\%). Although 'Seascape', 'San Andreas', and 'Albion' had similar survival rates between years, 'Monterey' did not. Cultivars vary in their tolerance to low temperatures (Gagnon et al., 1990; Galletta and Bringhurst, 1990; Lindén et al., 2002), and multiple factors are believed to govern the survival of plants following low temperature exposure, including prior acclimation to cold, the developmental stage of plants, low temperature tolerance, and carbohydrate and $\mathrm{N}$ levels within the roots (Gagnon et al., 1990; Galletta and Bringhurst, 1990; Marini and Boyce, 1979; Turner et al., 1993). In the present study, before overwintering, plants were permitted to continuously flower and fruit until very late in the fall (8 Nov. 2017 and 1 Nov. 2018) when low temperatures froze fruit (Orde and Sideman, 2019). Gagnon et al. (1990) reported that DN plants that were continuously fruited into the fall months contained lower carbohydrates and $\mathrm{N}$ levels in the roots compared with plants that had flowers removed beginning in September, which resulted in a decreased cold hardiness in the continuously fruited plants. Therefore, continued harvests and regular fertilization into the late fall may have depleted carbohydrates in the present study, causing plants to enter the winter without sufficient reserves and resulting in reduced hardiness. Plants were also fruited 1 week later in 2017 than 2018, which may have further contributed to higher plant mortality in Spring 2018 than Spring 2019. Moving forward, the termination of fruit production earlier in the fall season may be a tool that can be used to reduce mortality rates over the winter (M.P. Pritts, personal communication), especially for particular DN cultivars that appear to have less overall cold tolerance.

It is conceivable that the colder minimum temperature experienced during Winter 2017-18 could have also contributed to the higher mortality rate in Spring 2018 than Spring 2019. The air temperature under winter protection reached a low of $0.3^{\circ} \mathrm{F}$ during Winter 2017-18, and only $5.1^{\circ} \mathrm{F}$ in Winter 2018-19 (Fig.
2). Marini and Boyce (1979) showed that when 'Catskill' was exposed to temperatures ranging from 27.8 to -4 ${ }^{\circ} \mathrm{F}$, colder temperatures resulted in greater plant mortality, with $50 \%$ mortality occurring at $9.5{ }^{\circ} \mathrm{F}$, and $100 \%$ mortality following exposure to $-4{ }^{\circ} \mathrm{F}$ (Marini and Boyce, 1979). Similarly, Palonen and Lindén (2002) identified a reduction in the number of flowers following exposure to $-10{ }^{\circ} \mathrm{C}\left(14.0^{\circ} \mathrm{F}\right)$, and reduced vegetative growth following exposure to $-12{ }^{\circ} \mathrm{C}\left(10.4^{\circ} \mathrm{F}\right)$. Temperatures did, however, fall below $10{ }^{\circ} \mathrm{F}$ a greater number of times in Winter 2018-19 than Winter 2017-18 and monthly average minimum temperatures were colder in Winter 2018-19.

Another obvious contrast between 2018 and 2019 experiments were the different winter protection strategies we used. Although straw mulch remains widely used for winter protection in our region, previous work in cold climates has shown that compared with straw or hay, rowcovers reduce plant damage and improve early-season and total marketable yields (Bornt et al., 1998; Dalman and Matala, 1997; Pollard and Cundari, 1988; Pollard et al., 1989; Pritts et al., 1989). Without replication, we cannot draw conclusions about the protective ability of straw vs. rowcover in the present experiment, but we do demonstrate that a single layer of $1.25-\mathrm{oz} / \mathrm{yard}^{2}$ rowcover was sufficient for protecting DN cultivars during Winter 2018-19 in Durham, NH.

Two important yield-related takeaways from the current study were that 1) plant survival rate was not necessarily a predictor of secondyear yield from the surviving plants, and 2) first-year yield was not an indicator of second-year yield potential. In 2019, cultivars with comparable survival rates had very different yield outcomes. For example, 'Cabrillo' and 'Albion' had similar mortality rates $(7 \%$ and $8 \%$ mortality, respectively) but marketable yield of 'Cabrillo' (adjusted for mortality) was $8904 \mathrm{~kg} \cdot \mathrm{ha}^{-1}$, whereas 'Albion' was only $409 \mathrm{l} \mathrm{kg} \cdot \mathrm{ha}^{-1}$. Similarly, 'Portola' had a better survival rate than 'Cabrillo' in 2019 (99\% vs. 93\% mortality, respectively), but produced less than half the marketable yield (4118 $\left.\mathrm{kg} \cdot \mathrm{ha}^{-1}\right)$. 'Albion' was the highest yielding cultivar during the first year of fruit production for both plantings (Orde and Sideman, 2019), but was low yielding in comparison with other cultivars in the spring seasons that followed. Interestingly, Lewers et al. (2020) also reported that 'Albion', 'Monterey', and 'Portola' produced lower yields in their second year than during the first year of production.

Perhaps the most interesting outcome of the present study was that in 2019, 'Cabrillo', 'San Andreas', 'Seascape', and low-tunnel 'Sweet Ann' produced greater marketable yields in the short 6-week spring season than they had during the planting's entire first year of fruit production in 2018, which spanned 18 weeks (Orde and Sideman, 2019). 'Cabrillo' and 'Seascape' were particularly notable for their exceptionally high marketable yields in 2019, which were 136.5 and $172.1 \mathrm{~g} /$ plant greater than first year yields in 2018, respectively (Orde and Sideman, 2019). When 'Seascape' plants were grown in pots and overwintered with straw in New York, they produced $\approx 130 \mathrm{~g} /$ plant the following year (AcunaMaldonado and Pritts, 2013), substantially less than the $298.6 \mathrm{~g} / \mathrm{plant}$ we reported for 2019 , but similar to the $115.1 \mathrm{~g} /$ plant we report for 2018 when straw mulch was used for overwintering. Lewers et al. (2020) also recently reported that 'San Andreas', 'Seascape', and 'Sweet Ann' tend to produce greater yields in the second year than the first, suggesting that this outcome is related to genotype and was not unique to our site.

There are many possible reasons for low second-year yields from cultivars that were productive in the first year. It is possible that, although plants appeared to survive the winter, temperatures were cold enough to damage plant tissues and reduce reproductive capacity the following spring. For example, Marini and Boyce (1979) reported that even when plants survived exposure to sublethal temperatures, the percentage of surviving plants that produced flowers and the number of flowers per plant were negatively related to low temperature exposure. Further, first-year fruiting can lead to lower total nonstructural carbohydrate levels in the leaf, root, and crown by late fall, which can decrease overall yield capacity the following year (Acuna-Maldonado and Pritts, 
2013). Another factor may be chilling hours, as cultivars vary in how chilling temperature and the accumulation of chilling units affects production (Lieten, 2009; Tanino and Wang, 2008; Tehranifar et al., 1998). There is also evidence that greater cumulative diurnal temperature differences during certain periods of development promote earlier flowering and result in greater yields months later (Tanino and Wang, 2008).

In assessing the winterhardiness of DN plants, we hoped to better understand if it would be worthwhile for growers in New England to overwinter a DN crop. The gross revenue presented in Table 3 does not take into account expenses associated with overwintering an established crop. These expenses include: 1) winter protection material costs, 2) labor costs associated with applying/removing winter protection, spring plant care (e.g., runner removal, fertility application, scouting) and harvesting $(2 \times /$ week for 6 weeks), and $3)$ miscellaneous material costs (e.g., picking containers, fertilizer). We did not measure labor costs in this study but observed that rowcover required less labor and time to apply than straw for the same field area. Row cover was also less expensive than straw, at $\approx \$ 4670 /$ ha, compared with $\$ 5189$ / ha for straw. Furthermore, if not damaged during the winter and properly stored during the off-season, rowcover can be re-used for multiple years. Assuming a 3-year lifespan for rowcover, rowcover costs are $\approx \$ 1557 /$ ha per year; $\approx 70 \%$ less expensive than straw.

New England strawberry growers report harvesting an average of $4700 \mathrm{lb} /$ acre $\left(5268.0 \mathrm{~kg} \cdot \mathrm{ha}^{-1}\right)$ from their strawberry crop in 2018; valued at $\$ 14,100 /$ acre $(\$ 34,841.9 /$ ha) (USDA-NASS, 2019). Presumably, the vast majority of this crop consisted of short-day cultivars, which do not produce any fruit in the year they are planted in the northeastern United States. This shows that growers are willing to invest in both first-year management and overwintering costs for a second-year crop of this value. Using these yields as a conservative baseline for the worthwhileness of overwintering a strawberry planting, the direct market value of 'Aromas', 'San Andreas', and 'Seascape' yields in 2018 exceeded this value, by $\$ 18,210 /$ ha, $\$ 8816 /$ ha, and $\$ 553 /$ ha, respectively. In 2019 , all cultivars had a direct-market crop value above this baseline, exceeding it by $\$ 2160 /$ ha to $\$ 60,807 /$ ha. Furthermore, the DN cultivars in the present study produced fruit the previous year, with marketable yields ranging from 3672 to $12,565 \mathrm{~kg} \cdot \mathrm{ha}^{-1}$ during this period (Orde and Sideman, 2019). Overall, the results from the present study indicate real profit potential from overwintering a DN crop into a second year in the northeastern United States.

\section{Conclusions}

We demonstrate that it is possible to overwinter DN strawberry plants in northern New England and that second-year spring yields are generally comparable to or exceed yields reported by commercial strawberry growers in the region. We also show that some DN cultivars may produce second-year spring yields that exceed their first-year production levels (notably San Andreas and Seascape). Low tunnels can be used to increase the percent marketable yield and may allow for earlier harvests. 'San Andreas' and 'Seascape' appear well-suited for overwintering, and 'Cabrillo' and 'Sweet Ann' are promising, but we were only able to evaluate these cultivars in 1 year. We recommend 'Albion' for its high first-year yields and eating quality, the latter of which suggests it may be worth overwintering even if plant mortality is slightly higher than other cultivars and second-year spring yields may be only moderate. By overwintering an existing DN planting of these cultivars, we anticipate that the direct market value of the subsequent crop would be valued at between $\$ 3899 /$ ha and $\$ 95,647 /$ ha, depending on cultivar and year.

\section{Literature cited}

Acuna-Maldonado, L. and M. Pritts. 2013. Seasonal patterns of carbohydrate and nitrogen accumulation and depletion in strawberry are affected by fruiting but not day neutrality. J. Amer. Pomol. Soc. 67(2):95-103.

Anderson, H., M.A. Rogers, and E.E. Hoover. 2019. Low tunnel covering and microclimate, fruit yield, and quality in an organic strawberry production system.
HortTechnology 29(5):590-598, doi: 10.21273/HORTTECH04319-19.

Bornt, C.D., J.B. Loy, W.G. Lord, and O.S. Wells. 1998. Annual strawberry production in New England. Proc. Natl. Agr. Plastics Congr 27:99-105.

Condori, B., D.H. Fleisher, and K. Lewers. 2017. Relationship of strawberry yield with microclimate factors in open and covered raised-bed production. Trans. Amer. Soc. Agr. Biol. Eng. 60(5):15111525, doi: $10.13031 /$ trans.12371.

Dalman, P. and V. Matala. 1997. The effect of cultivation practices on the overwintering and yield of strawberry. Acta Hort. 439:881-886, doi: 10.17660/ ActaHortic.1997.439.144.

Davis, T., M. Gómez, and M. Pritts. 2019. 2018 New York State berry market analyses: Pricing information of local berries. Cornell Univ. EB 2019-03. 15 Nov. 2020. <https://dyson.cornell.edu/ wp-content/uploads/sites/5/2019/ 07/Cornell-Dyson-eb1903.pdf>.

Durner, E.F. 2017. Long-day and nitrogen conditioning of 'Albion' strawberry (Fragaria Xananassa Duch.) enhances off-season field production. J. Hort. Sci. Biotechnol. 93(3):296-305, doi: 10.1080/ 14620316.2017.1370985.

Gagnon, B., Y. Desjardin, and R. Bédard. 1990. Fruiting as a factor in accumulation of carbohydrates and nitrogen and in fall cold hardening of day-neutral strawberry roots. J. Amer. Soc. Hort. Sci. 115(4):520-525.

Galletta, G.J. and R.S. Bringhurst. 1990. Strawberry management, p. 109-112. In: G.J. Galletta and D.G. Himekick (eds.). Small fruit management. Prentice Hall, Englewood Cliffs, NJ.

Lantz, W., H. Swartz, K. Demchak, and S. Frick. 2010. Season-long strawberry production with everbearers for northeastern producers. Univ. Maryland Ext. EB 401. 15 Nov. 2020. <https://www.sare.org/ wp-content/uploads/EverbearingStrawberry-Guide.pdf>.

Laugale, V., S. Dane, L. Lepse, S. Strautina, and I. Kalnina. 2017. Influence of low tunnels on strawberry production time and yield. Acta Hort. 1156:573-578, doi: 10.17660/ActaHortic.2017.1156.85.

Lewers, K. 2015. Low-tunnel production of strawberry: Learning more every year. 15 Nov. 2020. <https://www.ars.usda. gov/northeast-area/beltsville-md-barc/ beltsville-agricultural-research-center/ genetic-improvement-for-fruits-vegetableslaboratory/docs/low-tunnel-strawberryproduction-2013/>.

Lewers, K.S., D.H. Fleisher, and C.S.T. Daughtry. 2017. Low tunnels as a strawberry 
breeding tool and season-extending production system. Intl. J. Fruit Sci. 17(3):233-258, doi: 10.1080/15538362.2017.1305941.

Lewers, K.S., D.H. Fleisher, C.S.T. Daughtry, and B.T. Vinyard. 2020. Low-tunnel strawberry production: Comparison of cultivars and films. Intl. J. Fruit Sci. 20(1):1-28, doi: 10.1080/15538362.2020.1768616.

Lieten, P. 2009. Chilling requirements of strawberry cv. 'Sonata' and 'Figaro'. Acta Hort. 842:749-752, doi: 10.17660/ActaHortic.2009.842.163.

Lindén, L., P. Palonen, and T. Hytönen. 2002. Evaluation of three methods to assess winter hardiness of strawberry genotypes. J. Hort. Sci. Biotechnol. 77(5):580-588, doi: 10.1080/14620316.2002.11511542.

Marini, R.P. and B.R. Boyce. 1979. Influence of low temperatures during dormancy on growth and development of 'Catskill' strawberry plants. J. Amer. Soc. Hort. Sci. 104(2):159-162.

Maroto, J.V., S. López-Galarza, B. Pascual, and J. Alagarda. 1989. The influence of different plastic materials over low tunnels on earliness, productivity and several quality parameters in strawberry crop (Fragaria xananassa) on the Spanish Mediterranean coast. Acta Hort. 265:299-302, doi: 1017660/ActaHortic.1989.265.44.

Orde, K. and B. Sideman. 2019. Low tunnel and cultivar effects on day-neutral strawberry yield and characteristics in New Hampshire. HortTechnology 29(6):795-809, doi: 10.21273/HORTTECH04317-19.

Palonen, P. and L. Lindén. 2002. Winter survival of strawberry as affected by the type of planting material. Acta Hort. 567:329-332, doi: 10.17660/ActaHortic.2002.567.70.

Petran, A., E. Hoover, L. Hayes, and S. Poppe. 2016. Yield and quality characteristics of day-neutral strawberry in the United States upper midwest using organic practices. Biol. Agr. Hort. 33(2):73-88, doi: $10.1080 / 01448765.2016 .1188152$.

Pike, D. 2011. Day-neutral strawberries: Making it work. New England Veg. Fruit Conf. Trade Show Proc. 2011:75-76. 15 Nov. 2020. <https://newenglandvfc. org/sites/newenglandvfc.org/files/ content/proceedings $2011 /$ strawberrypike.pdf>.

Pollard, J.E. and C.M. Cundari. 1988. Over-wintering strawberry plants under rowcovers increases fruit production. HortScience 23(2):332-333.

Pollard, J.E., K.L.B. Gast, and C.M. Cundari. 1989. Overwinter rowcovers increase yield and earliness in strawberry. Acta Hort. 265:229-234, doi: 10.17660/ ActaHortic.1989.265.34.

Pritts, M. 2016. Extending local strawberry production using day neutral cultivars and low tunnel technology. 15 Nov. 2020. <http://www.hort.cornell.edu/ expo/proceedings/2016/Berries. Extending\%20local\%20strawberry\% 20production $\% 20$ using $\% 20$ day $\% 20$ low $\%$ 20tunnel\%20technology.Pritts.pdf>.

Pritts, M. 2017. Protected culture for berries, low and high tunnel research. 15 Nov. 2020. <https://www.youtube. $\mathrm{com} /$ watch?v $=5$ ErlnTZNuxM>

Pritts, M. and D. Handley. 1998. Strawberry production guide for the Northeast, Midwest, and eastern Canada. Northeast Reg. Agr. Eng. Serv. (NRAES), Ithaca, NY.

Pritts, M. and L. McDermott. 2017. Protected culture for strawberries using low tunnels. 15 Nov. 2020. <http:// www.hort.cornell.edu/fruit/pdfs/lowtunnel-strawberries.pdf $>$.

Pritts, M.P., K.A. Worden, and M. Eames-Sheavly. 1989. Rowcover material and time of application and removal affect ripening and yield of strawberries. J. Amer. Soc. Hort. Sci. 114(4):531-536.

Resende, J.T.V., R.G.F. Morales, M.V. Faria, A.L.L. Rissini, L.K.P. Camargo, and C.K. Camargo. 2010. Produtividade e teor de sólidos solúveis de frutos de cultivares de morangueiro em ambiente protegido. Hort. Bras. 28(2):185-189, doi: 10.1590/S010205362010000200008 .

Schloemann, S. 2004. Winter mulch for strawberries. 25 Nov. 2020. <https:// cpb-us-el.wpmucdn.com/blogs.cornell. edu/dist /0/7265/files/2016/12/ strwintermulch-zjdbrf.pdf $>$.

Sønsteby, A. and O.M. Heide. 2007. Long-day control of flowering in everbearing strawberries. J. Hort. Sci. Biotechnol. 82(6):875-884, doi: 10.1080/ 14620316.2007 .11512321 .
Tanino, K.K. and R. Wang. 2008. Modeling chilling requirement and diurnal temperature differences on flowering and yield performance in strawberry crown production. HortScience 43(7):2060-2065, doi: 1021273/HORTSCI.43.7.2060.

Tehranifar, A., P. Le Miere, and N.H. Battey. 1998. The effects of lifting date, chilling duration and forcing temperature on vegetative growth and fruit production in the Junebearing strawberry cultivar Elsanta. J. Hort. Sci. Biotechnol. 73(4):453-460, doi: 101080/14620316.1998.11510998.

Turner, J.M., K.K. Tanino, and C. Stushnoff. 1993. Evaluation of low temperature hardiness of strawberry plants under field and controlled conditions. Can. J. Plant Sci. 73:1123-1125, doi: 104141/cjps93-151.

University of New Hampshire. 2020. Commercial plant tissue test. 2 Nov. 2020 $<$ https://extension.unh.edu/resources/ files/Resource002488_Rep3658.pdf>.

U.S. Department of Agriculture (USDA). 2006. United States standards for grades of strawberries. 9 Nov. 2020. <https:// www.ams.usda.gov/sites/default/files/ media/Strawberry_Standard\%5B1\%5D. pdf>.

U.S. Department of Agriculture (USDA). 2012. Plant hardiness zone map. 15 Nov. 2020. <https://planthardiness.ars.usda. gov $/ \mathrm{PHZMWeb} />$.

U.S. Department of Agriculture, National Agricultural Statistics Service (USDANASS). 2019. New England vegetable and strawberry report, 2018 crop. U.S. Dept. Agr., Washington, DC.

Van Sterthem, A., Y. Desjardins, L. Gauthier, Y. Medina, and A. Gosselin. 2017. Use of low tunnels to improve the productivity of day-neutral strawberry plants under the Québec climatic conditions. Acta Hort. 1156:555-562, doi: 1017660/ActaHortic.2017.1156.82.

Weber, C., R. Gassier, K. Kuehn, and M.P. Pritts. 2018. Yield of day-neutral strawberries grown under low tunnels is affected by planting date. HortScience 53(9):S171 (abstr.).

Willden, S.A., K.D. Cox, M.P. Pritts, and G.M. Loeb. 2021. A comparison of weed, pathogen and insect pests between low tunnel and open-field grown strawberries in New York. Crop Prot. 139:105388, doi: 101016/j.cropro.2020.105388. 